directly through the mediun of the valves." $*$ There can be no doubt that a considerable portion of tendinous fibres pass from the insertion of the cords to the zones, and many of the smaller cords themselves pass up directly into the angle formed between the under surface of the valve and the inner surface of the ventricles, and at once enter into the formation of the fibrous zones. These cords are gencrally short, and many of them spring from the wall of the ventricle buthind the valve. Therefore, it results that these zones are densest and most strongly marked in those portions corresponding to the attached borders of the valves, and gradually become less distinct towards the intervals between them. It has been generally noticed that the left zone is altogether denser and stronger than the right. Thus it is, as has been already suggested, that the greater portion of the auriculoventricular zones is more properly to be considered in relation with the valves.

The most superficial glance at any one of these valves will show how unequally the tendinous tissue is distributed throughout their substance, and that it exists in great abundance along their attached margins, which are thus much thickened and condensed. The upper attached portion of the anterior mitral valve also receives its fibrous tissue from anoth $\mathrm{r}$ sonrce-viz. from that layer already described as descending a short distance into its substance from the inferior border of the arterial wall. It has also been mentioned that in th s layer of fibrous tissue a moderate quantity of yellow elastic tissue is blended, and these fibres are therefore found in the upper portion of the mitral valve. Is it confined to this situation? and does it exist in the other valves? The presence of elastic tissue in any of the valves does not appear to have been noticed. It has been described as existing abundantly beneath the lining membrane of the auricles, but is said to be absent beneath the lining membrane of the ventricles, and in the valves. In numerous examinations it has been found very scantily scattered beneath the lining meanbrane of the ventricles, except, perhaps, over the columna carnes, where the membrane is especially thin; but in the auriculo-ventricular valves it may be found more abundantly, especially in the thickened portions, and near their attached borders, beneath the under as well as the upper surface. It exists more plentifully in the anterior mitral valve, especially towards the upper part. It may also be detected in the chordee tendineæ. It is, however, more abundantly found in the arterial than in the auriculo-ventricular valves.

Lastly, are muscular fibres contained in the auriculo vertricular valves? Their presence has been alternately affirmed and denied. Dr. Reidy asserts that they do not exist in the valves of the human heart, and says, "in making examinations of this kind we must be exceedingly careful not to mistake the tendinous fibies when they are tinged with blood for muscular fibres; for under these circumstances," he continues, "they certainly at ail times assume the appearance of muscular fibres." If the microscope be employed, this mistake is not likely to happen. Lancisił and Senac $\$$ long since described muscular fibres in the segments of the auriculo-ventricular valves, and Kürschner has more recently confirmed the observation. He says, "The auriculo-ventricular valves are composed (besides their proper tissue and the endocardium) of the continuation of the tendinous cords, which usually spread out like palm-leaves, and are interwoven; and of muscular fibres, of which a certain number may be traced (especially after several days' soaking in cold water) passing from the adjacent wall of the auricle into the interior of each division of the valves, and connecting themselves with the ends of the tendons of the second order in the central portion of the valve." $\|$ The existence of muscular fibres in the valves is not generally admitted. Probably these contradictory statements may be in some measure reconciled by a consideration of the arrangement already described, and by a reference to the sketches. The internal fibres which have been mentioned, descending from the auricular walls into the valves just beyond their attached margins, may be traced to a greater distance into their substance in some cases than iu others. They generally terminate by a tolerably welldefined margin; but this varies. They usually descend for a greater distance between the layers of the anterior mitral valve, immediately in front of its auricular surface; but even here they are seldom found stretching far into the valve-not terminating, however, so abruptly. Although extending below the attached bases of the semilunar valves, I have never succeeded in tracing them so far as the central portion of the valve, as described by Kürschner; and it is difficult to conceive what advantage is gained by previously soaking the valves for several days in cold

* Anatomie Descriptive, par J. Cruveilhier, vol. iii. p. 24 + Cyclopædia of Anatomy and Physiology, vol. ii. p. 589 ¥ De Motu Cordis.

$\$$ Traité de la Structure du Cour, livre i. p. 76 Il Mr. Paget's Reports for $16 \star 3$, p. I. water, if the microscope be employed; and without this instrument, observation will be of little value, for we are very likely to fall into the error before alluded to by Dr. Reid. Therefore, if a portion of the attached border of a valve, inmediately below its upper surface, be examined, muscular fibres in abundance will generally be detected; whereas, if sought for in any other portion of the valve far from its attached border, according to the foregoing observations, they will not be found.

It may be well, in conclusion, to enumerate the principal points which have been discussed in the preceding pages. An attempt has been made to explain,-

The real connexion that exists between the auricles and ventricles, and their relation to the fibrous rings; the formation of the grooves in which the cononary vessels lie, \&c.

The nature and mode of formation of the "tendinous festooned rings" surrounding the arterial orifices.

The exact connexion existing between the semilunar valves and the upper border of the ventricles, upon which a portion of the valres rests, and by which they are supported.

The different tissues entering into the formation of the arterial and auriculu-ventricular valves; the comexion between the muscular tissue of the auricles, and the auriculo-rentricular valves.

The relation of the antic to the left auriculo-ventricular orifice, and the construction of the anterior mitral valve.

\section{CASES OF INTERMITTENT AND REMITTENT FEVER, OCCURRING AT SEA. WITH REMARKS.}

By LESLIE O. PATTERSON, M.R.C.S. Eng. FORMERLY SURGEON TO THE EAST INDIA SMIP "CARNATIC."

DURING the months of April and May last, a very peculiar and interesting form of intermittent anå remittent fever prevailed on board the East India ship Carnatic, during her royage from Bombay to England. Having never seen a similar epidemic, and not recollecting ever reading of one like it occurring at sea, I am induced to send a brief acoount of it, trusting that a pernsal of the cases may prove of service to those members of the profession who may be intending a trip to the "Diggings," or elsewhere, in emigrant or other ships, in which the namber of passengers is necessarily great, and where, a similar cause being in existence, a like result would probably follow, while by its timely discovery and removal, an immensity of trouble and anxiety would be saved to the surgeon, and a world of suffering and annoyance to those under his care.

CASE 1.-Mr. S-, aged twenty-one years, an officer of the ship, was seized during the night of the 2 nd of April, with very intense headache, which continued gradually increasing for some time in violence. In two hours after its commencement he had a well-marked rigor, which lasted for about ten minutes. This was succeeded by a hot stage, which, haviug existed for three hours, gradually declined, and was followed by a very profuse persuiration.

On the morning of the 3rd, when I visited him, he complained of great pain in the head; considerable vertigo; pain and aching in the bones, joints, and lumbar region; great thirst; tongue dry and loaded; no sickness; bowels constipated; slight tenderness over the abdomen on pressure; urine high-coloured and scanty, depositing lithates; pulse full, 90 ; auscultation and percussion discovered the heart and lungs to be healthy; skin hot and dry. Compound senna mixture, an ounce and a half; to be taken immediately. Febrifuge mixture, to six ounces; a tablespoonful every fourth hour.- Noon: States that he feels somewhat better, but complains of great lassitude and prostration of strength; pain in the head no better; bowels freely opened. skin cool and moist.-Six P.M.: Has had another rigor of similar duration to the firs ; is now in the hot stage; great wakefulness ; no delirium.-Eleven P.M.: The hot stage lasted for about two hours, and was succeeded, as in the first instance, by copious perspiration; I now loolsed upon the case as one of intermittent fever (quotidian), and ordered the following mixture: Sulphate of quinine, ten grains; dilute sulphuric acid, thirty drops; infusion of roses, half an ounce; add water to six ounces. A table. spoonful to be taken every third hour.

4th. - Passed a sleepless night; has had another rigor; complains of the constancy of the headache and the great wakefulness which prevents any approach of sleep. In all other respects as yesterday. Continue the medicine.-Evening : somewhat im. proved; pulse 84; less headache and vertigo; skin cool and moist; no inclination for sleep. Dover's powder, ten grains; to be taken inmediately.

5 th.-Evening: Has had a return of all the symptoms, though in a somewhat milder form. Continue the quinine. 
6th.-Considerably better; has had no return of the rigor. Passed a good night; less headache; pulse 80 ; skin moist and cool ; tongue cleaning ; less thirst; complains of complete loss of strength; is greatly emaciated. Continue medicine.

12th.-Has had but one return of the symptoms since last report; may now be prononnced convalescent; is still, however, so much debilitated that he can hardly walk without assistance. To take good nourishing diet, with porter or wine.

20th.-Much better; allowed to do duty during the day.

Attacks similar to the above went through the whole of the midshipmens' berth to which Mr. S- belonged. Out of eight inmates, one only escaped.

CASE 2.- May lst. Mrs. C.- upon going to bed last night felt perfectly well, but was seized about one A.M. with a most excruciating pain in the head, followed by a distinct attack of shivering, which, having continued for a period of fifteen minutes, was in its turn succeeded by a feverish or hot stage. In the morning, when I saw her, she complained of headache and vertigo; eyes suffised, and painful upon exposure to light; tongue dry and coated; complete loss of appetite ; no sickness; bowels tolerably regular; no tenderness of the abdomen on pressure; great pain in the legs. joints, and back ; skin very hot and dry; pulse 94 , tolerably full. Heart-sounds normal; lungs healthy; urine of natural specific gravity, but scanty in amount. Has had no perspiration.

This case was therefore precisely analogous to the first, with this exception-it wanted the third, or sweating stage. Acting upon the belief that it was closely allied in its nature to the first, I commenced at once with the quinine mixture.

2nd.-During the past night has had a rigor, followed by fever, as yesterday. The febrile attack, from its commencement, kept steadily increasing, till it arrived at a certain height, and then as gradually subsided, never, however, entirely disappearing. Great lassitude; considerable thirst; desire, but inability to sleep; bowels freely open. Continue the medicine.

This state of things continued till the evening of the 5th, when a profuse diaphoresis set in. In a few hours after, all the unpleasant symptons disappeared, the patient passed a good night, and in the morning was considerably more comfortable, having lost the headache and vertigo; the thirst had greatly diminished, and she felt a slight desire for food. Complained of great weakness, and slight pain in the legs and back. Continue the medicine. She suffered no relapse, and mended rapidly.

Attacks similar to the two preceding cases ran through the whole ship's company; those of the purely intermittent form being, however, the more numerous.

As to treatment, I tried every method at my disposal. Venesection, with calomel and opium; arsenic; quinine; diaphoretics, \&c.; and at last came to the conclusion that it mattered little which was tried, the disease apparently running its own course, and terminating in the majority of cases by the fifth or sixth day. In one or two cases where no treatment was employed the attack terminated at the same time, the patients making as speedy a recovery as in the other instances.

Remarks. - I think the above cases interesting, inasmuch as they were well-marked cases of intermittent and remittent fever, occurring without any previous or present (so far as could be ascertained) exposure to malaria of any kind; commencing after we had been at sea for three or four weeks. The suddenness of the attack; the intense, the awful pain in the head; the great wakefulness; and the total prostration of strength, with the comparatively speedy return to health, also seem to me interesting points, as connected with the disease. The little control which medicine had over it, is also worthy of remark; and last, though not least, they are interesting, as showing that the same poison acting under similar circumstances, but upon different individuals, will in one produce intermittent, and in the other, remittent fever.

The ship was free from any offensive smell from bilge water, or other source; till one day, at the end of May, the steward in clearing away for provisions, broached a cask of eggs, the smell from which was most intolerable; they were all rotten, and of course immediately thrown overboard. Strange to say, with them the disease disappeared. I may also remark that the place where the epidemic first showed itself-namely, in the midshipmens' berth-was the cabin nearest to the store-room, and that here the attacks were more violent than in any other portion of the vessel. It is right, however, to state that many of those who suffered were never near this part of the ship. Whether this was the exciting cause of the disease or no, I am of course unable to determine; but I must say I am strongly of opinion that it was. If not, $I$ am quite at a loss to account for the appearance and disappearance of the attack. To say the least of it, the latter was an extraordinary coincidence.

Downhain Market, Norfolk, 1852.
A $\mathfrak{A}$ tíror

OF THE PRACTICE OF

\section{MEDICINE AND SURGERY IN THE} HOSPITALS OF LONDON.

Nulla est alia pro certo noscendi via, nisi quam plurimas et morborum, et dissectionum historias, tum aliorum proprias, collectas habere et inter se comparare,-Morgagnr. De Sed. et Caus. Miorb,, lib.14. Procmium.

KING'S COLLEGE HOSPITAL.

Large Calculus in the Female, of which the Nucleus was a piece of Cork; Previous Paraplegia; Extraction; Recovery.

(Under the care of Mr. Partridge and Mr. Henry LeE.)

From the great number of cases of stone in the bladder which are met with, both in private and hospital practice, it may be inferred that our mode of life, and the nature of the ingesta in all ranks of society, are pretty favourable to vesical concretions. The actual circumstances which give rise to the formation of calculi, either in the kidney or bladder, have been extensively studied and elucidated; it may, indeed, be said, that a great deal is known on the subject; and we gladly refer to a course of lectures, by Mr. Coulson, publishing in this journal, which show that much is being done in this particular direction. But there is a point of some importance, which seems to be still rather ill-understood; and that is, tho very strong tendency to alkaline urine, and the subsequent formation of phosphatic stone in the bladder of patients affected with paraplegia. Dr. Watson expresses himself as follows in his Lectures on the Practice of Physic:-

"Do not forget the important fact, that in many-nay, in most cases of paraplegia, the urine at length becomes ropy, alkaline, and ill-smelling; and the bladder, after death, presents appearances such as chronic inflammation might produce-roughness and redness of its inner surface, and thickening of its coats. What may be the order and relation of these changes, I confess I do not know: whether the quality of the urine is first altered, and then the bladder suffers from the perpetual contact of this unnatural secretion, or whether the bladder becomes diseased in consequence of the palsy, and pours forth unhealthy mucus, whereby the quality of the urine is affected,-has not, I believe, been clearly ascertained."

Dr. Watson goes on to say, that the urine has been found acid after the bladder had been washed ont, and also acid in the pelvis of the kidney, though it has been known to be secreted alkaline. But as to an explanation of these pathological phenomena, the following passage of the same author comes very near the truth:- "The disorganization of the bladder, and the alkaline quality of the urine, may both have been common results of the interruption of the nervous influence." This explanation is the more likely to be correct, as, without nervous influence, nutrition is imperfect, and the secerning process of an altered and defective kind.

That with a highly alkaline state of the urine phosphatic calculi should form in the bladder, is a fact easily understood; and hence the numerous cases of stone connected with paraplegia. We have heard Dr. Budd relate, in his clinical lectures, an extremely interesting case of paraplegia which occurred in his private practice, in which calculi formed again and again after operation,-this circumstance clearly showing that the effects remain ever the same, as long as the nervous influence is absent, or much altered. The present case offers this peculiarity, that the formation of stone during paraplegia was considerably favoured by the presence of a vucleus of a rather unusual description, being a piece of cork. The loss of power in the lower extremity was recovered from, but the calculus (it would seem) continued to increase, and after a lapse of years attained a size seldom to be seen with female patients. The case, as noted by Mr. Ray, one of Mr. Partridge's dressers, runs as follows:-

Jane $\mathbf{P}$ - aged forty-two, married, was admitted Oct. 20, 1852, under the care of Mr. Partridge, suffering from stone in the bladder. Until four years ago, she seems to have enjoyed excellent health; about that time she was admit ted into University College Hospital, probably for an attack of pleurisy. Two years before her present admission, she was in this hospital, under the care of Dr. 'Todd, for paraplegia, but was able 